Revista Brasileira de Odontologia Legal - RBOL

\title{
Forensic odontology
}

\section{THE NEED FOR IMPLANT DENTISTS TO KNOW ABOUT THE METHOD OF FORENSIC HUMAN IDENTIFICATION USING DENTAL IMPLANTS.}

\section{A necessidade que implantodontistas conheçam a técnica de identificação humana forense pelos implantes dentais.}

\author{
Geraldo Elias MIRANDA ${ }^{1,2}$, Adriana Maria Carneiro MOREIRA ${ }^{1}$, Rodolfo \\ Francisco Haltenhoff MELANI ${ }^{2}$. \\ 1. Institute of Legal Medicine, Civil Police of Minas Gerais, Minas Gerais, Brazil. \\ 2. Laboratory of Anthropology and Forensic Dentistry - OFLAB, Social Department, Dental School, University of São \\ Paulo, São Paulo, Brazil.
}

\begin{tabular}{ll}
\hline Information about manuscript & Autor para contato: \\
Received: 14 Nov 2019 & Geraldo Elias Miranda \\
Accepted: $19 \operatorname{Dec} 2019$ & Laboratory of Anthropology and Forensic Dentistry \\
& OFLAB, Dental School, University of São Paulo \\
& Av. Prof. Lineu Prestes, 2227, São Paulo. 05508-000. \\
& E-mail: geraldoelias@usp.br.
\end{tabular}

\begin{abstract}
The aim of this study is to present two cases in which dental implants greatly enhanced the forensic human identification and to show the important role of the implant dentist in this process. The skeletonized remains of two victims with dental implants were sent for exams. The morphological features (qualitative) and linear measurements (quantitative) of the implants were analyzed in the ante-mortem and postmortem radiographs. The points of coincidence observed in both the implants and teeth showed compatibility of findings that led the experts to determine the positive identification. The implants found in the bodies were decisive in the process of identification. This identification was only possible because the implant dentists presented complete documentation with good technical quality, enabling an efficient expert approach to comparison of the data. Therefore, it is important to make implant dentists aware of this significant role because they may be asked by the authorities or family members of the deceased to present a complete record chart.
\end{abstract}

\section{KEYWORDS}

Forensic sciences; Forensic odontology; Dental implants; Human identification; Dental radiography.

\section{INTRODUCTION}

Over the last few years, dental implants have been used increasingly, making them an important element of human identification $^{1,2}$. The number of implants has been a direct consequence of modern dentistry, advancement of surgical techniques, predictable results and reduced costs, making this treatment accessible to all patients ${ }^{3}$. This has increased the probability of dental implants being present in unidentified bodies and detected in postmortem (PM) exams ${ }^{4,5}$.

Dental implants are crucial in a forensic scenario because they may be the only element available for an identification, especially in charred, putrefied or fragmented human remains, in which not 
even DNA can be used ${ }^{6}$. These cases may occur due to terrorist attacks, mass disasters, fires, death of refugees, etc. Therefore, concerning the comparative process, an implant dentist may be requested to provide a record chart with dental information about the treatment performed for the patient so that these records may be used as ante-mortem (AM) material.

When dental implants are osseointegrated, their position in relation to the surrounding anatomic structures does not change ${ }^{6}$. This is a fundamental operational requirement because dental identification is based on a morphological comparison between the $\mathrm{AM}$ and $\mathrm{PM}$ features ${ }^{6}$. Few studies in the literature have shown real cases of human identification by means of implants ${ }^{6}$; therefore, more studies must be conducted, comparing AM and PM data to verify the success of identification by means of implants ${ }^{2}$.

The aims of this study are to present two cases in which dental implants greatly enhanced the identification process and to show the important role of the implant dentist in keeping complete and updated patient record charts.

\section{CASE REPORT}

In 2016, two skeletonized remains without relationship (one was partially charred - individual 01) were sent to the Legal Medical Institute of Belo Horizonte, Brazil. Anthropological analyses indicated the biological profile of each individual (estimated age, stature, sex) determining the identity of possible victims. After dental exam, was observed that there were dental implants in the posterior arches of both individuals (Fig. 1 and 2).

The families of the supposed victims brought the dental records provided by the implant dentist, which served as AM material for forensic dental comparison. The forensic dentists took PM radiographs (Fig. 3 and 4) at the same angulation as that of the AM radiographs, with the purpose of comparing them. The comparison between AM and PM data is in the tables 1 and 2 , as done previously in other study ${ }^{7}$.
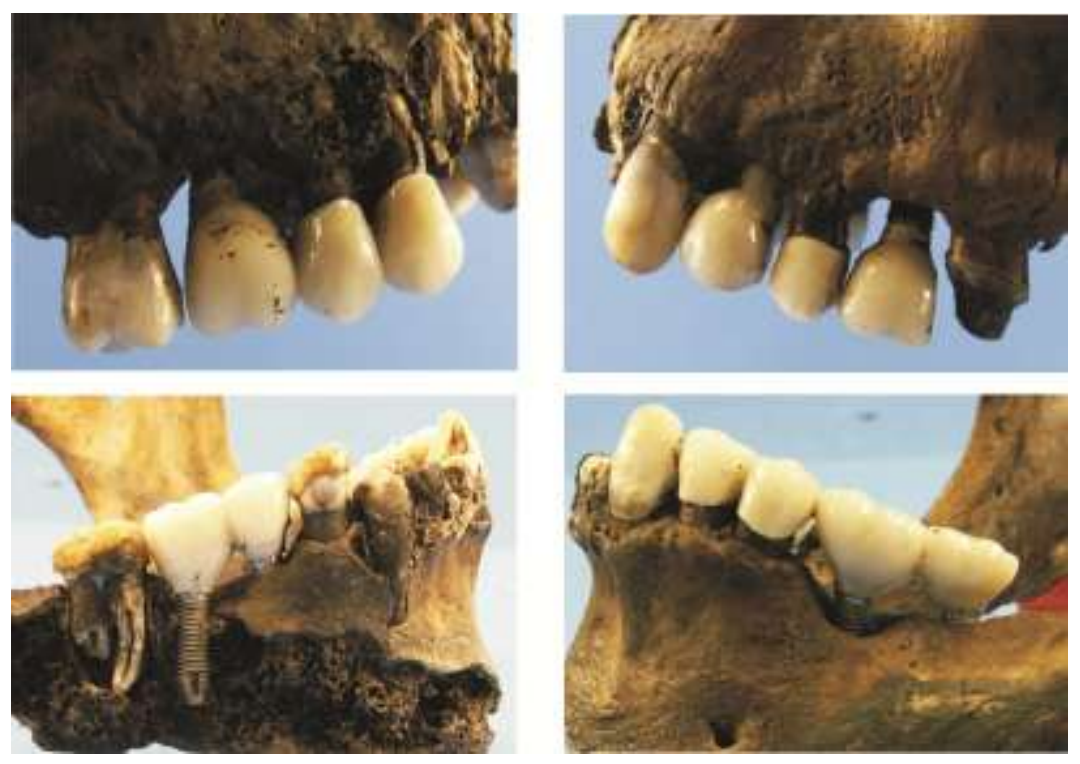

Figure 1 - Lateral view of dental arches of individual 01. 

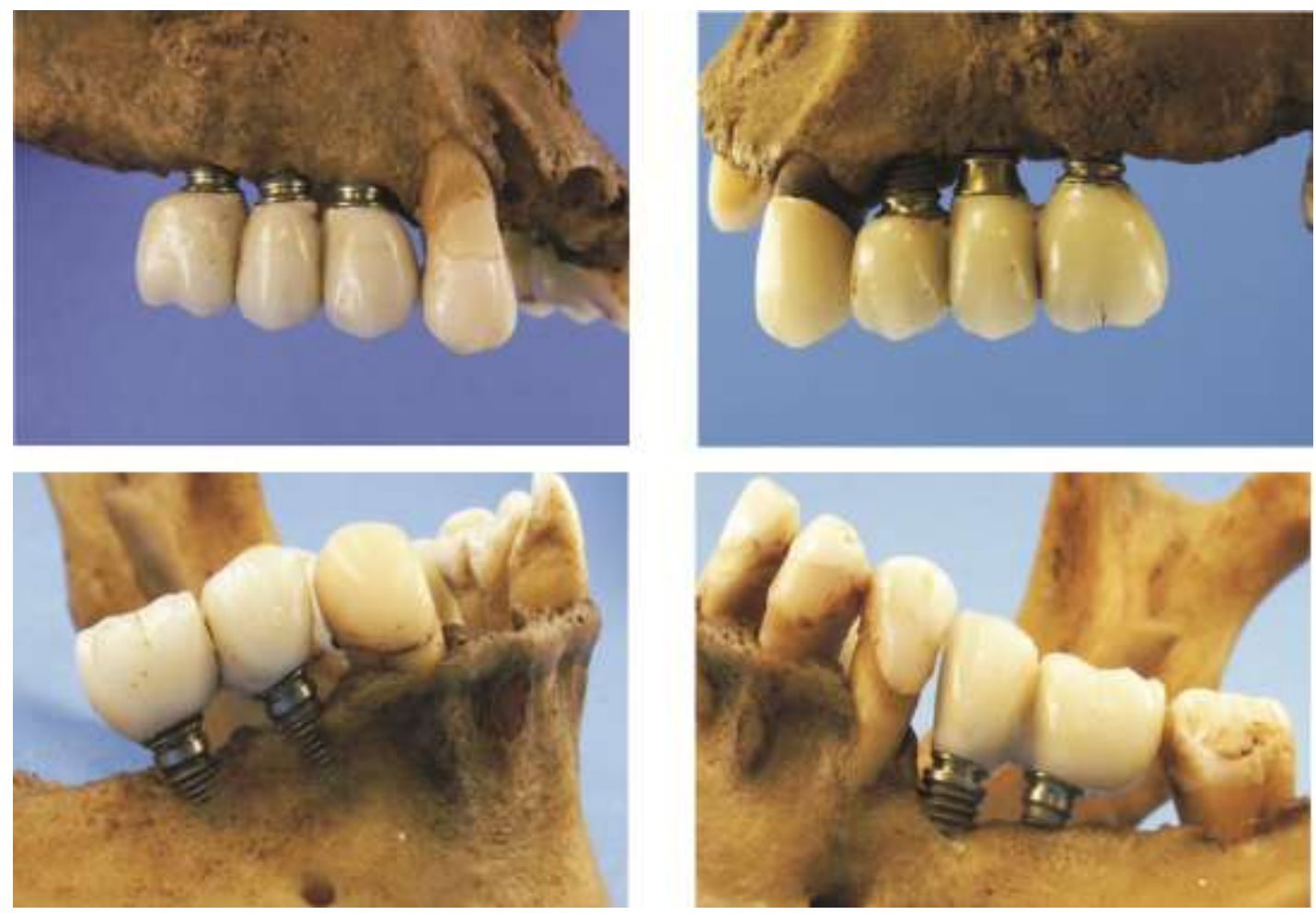

Figure 2 - Lateral view of dental arches of individual 02.
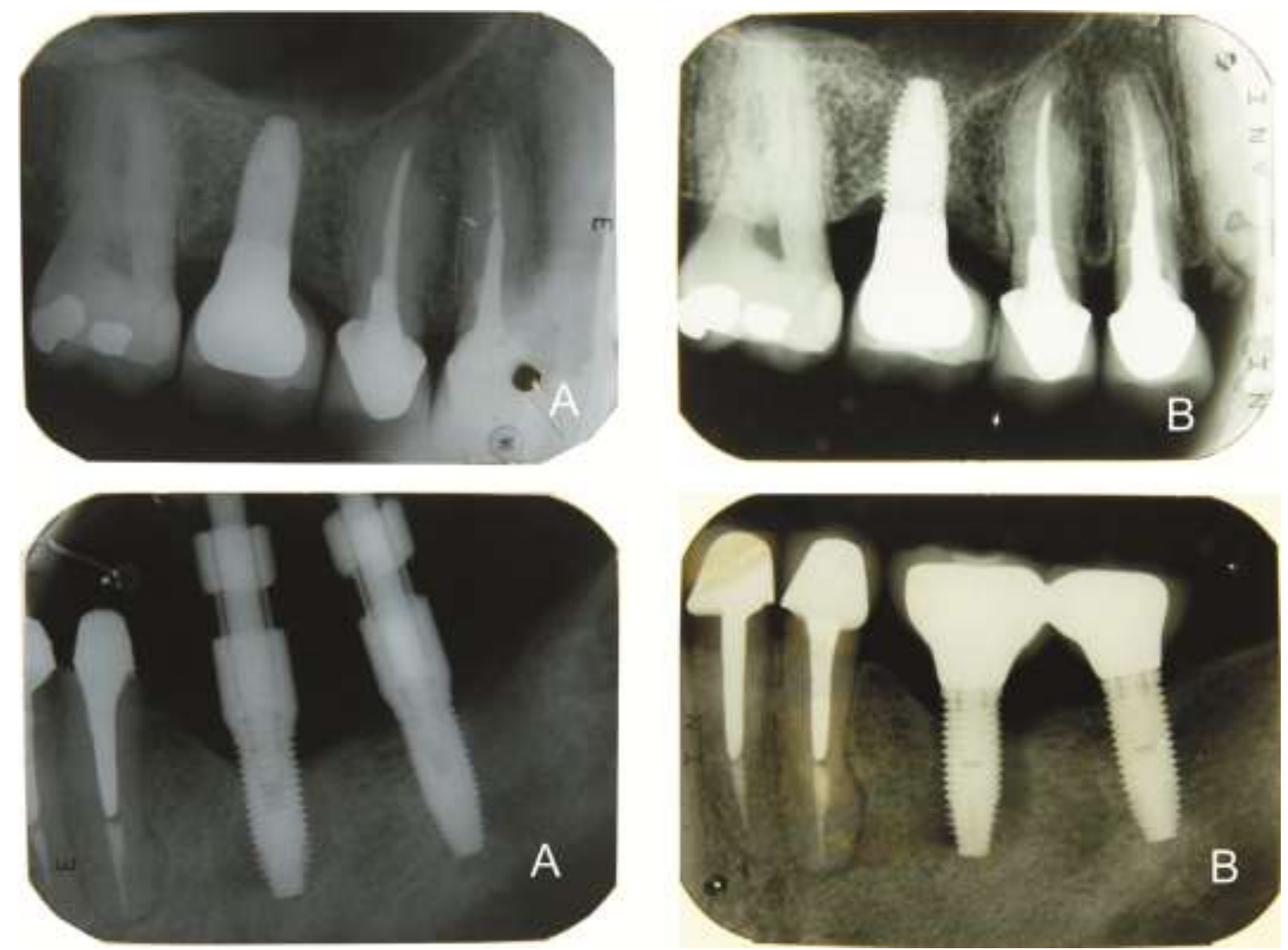

Figure 3 - AM (A) and PM (B) periapical radiographs of the individual 01. 

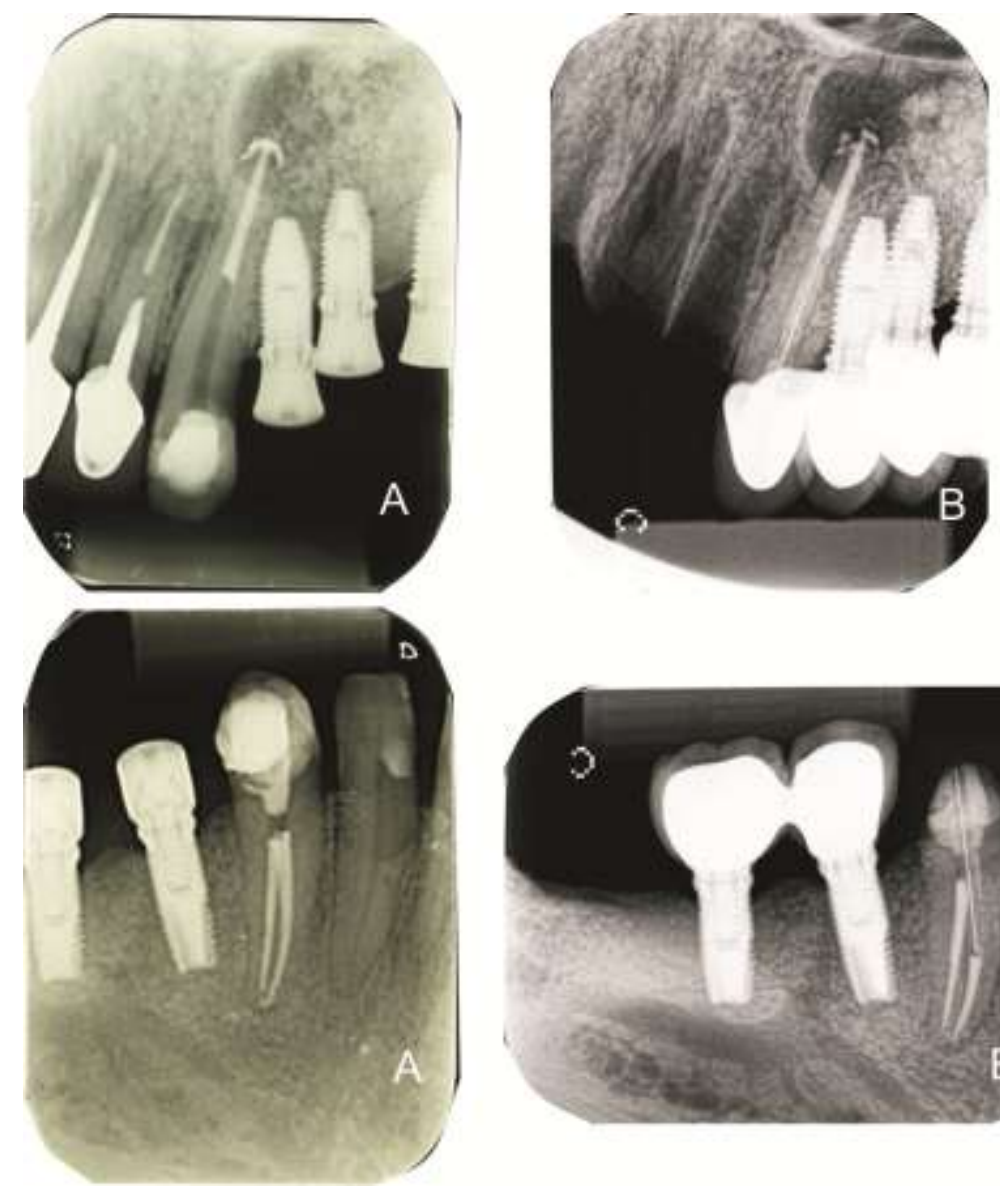

Figure 4 - $\mathrm{AM}(\mathrm{A})$ and $\mathrm{PM}(\mathrm{B})$ periapical radiographs of the individual 02.

Table 1: Dental features and comparison of the individual 1.

\begin{tabular}{cccc}
\hline Implant/tooth & AM data & PM data & Comparison \\
\hline 15 & Root filling, post and crown & Root filling, post and crown & Similarity \\
16 & Implant and crown & Implant and crown & Similarity \\
17 & Amalgam filling & Amalgam filling & Similarity \\
35 & Root filling, post and crown & Root filling, post and crown & Similarity \\
36 & Size and diameter of the implant & Size and diameter of the implant & Similarity \\
37 & Size and diameter of the implant & Size and diameter of the implant & Similarity \\
\hline
\end{tabular}

Table 2: Dental features and comparison of the individual 2.

\begin{tabular}{cccc}
\hline Implant/tooth & AM data & PM data & Comparison \\
\hline 23 & Root filling & Root filling & Similarity \\
24 & Size and diameter of the implant & Size and diameter of the implant & Similarity \\
25 & Size and diameter of the implant & Size and diameter of the implant & Similarity \\
44 & Root filling & Root filling & Similarity \\
45 & Size and diameter of the implant & Size and diameter of the implant & Similarity \\
46 & Size and diameter of the implant & Size and diameter of the implant & Similarity \\
\hline
\end{tabular}

\section{DISCUSSION}

Implants and their site of integration are frequently peculiar characteristics due to morphological diversity, dimension, anatomic location, and screw orientation ${ }^{6}$. Moreover, proximity to anatomic structures such as the cortical bone, roots of teeth, mandibular canal, and maxillary sinus make implants especially useful for purposes of human identification ${ }^{6}$. In the cases described, both individuals had teeth and other anatomic structures that contributed to a more precise analysis when associated with the implants. It may be observed, for 
example, that even though there were postmortem losses of teeth 21 and 22 (Fig. 4), the contour of the dental alveoli remained preserved, serving as a reference.

One study showed that confidence in the identification increased when it was associated with the prosthetic part of the implant ${ }^{5}$. However, the cited author ${ }^{5}$ studied mandibles completely rehabilitated with implants. Implants are mass-produced; therefore, they lack the individuality that occurs with restorations made by hand by the dentist ${ }^{8}$. In the related cases, even with the absence of the prostheses in the AM radiographs, it was possible to verify the relationship of the implants with the surrounding anatomic structures in the PM radiographs and determine that there had been prostheses inserted (Fig. 2 and 4). Therefore, the implant-supported dental prostheses did not influence the identification process because they were present in the PM radiographs and absent from the AM radiographs.

Greater precision for identification of the victim could occur if each implant had an individual serial number engraved on it ${ }^{9}$, as already occurs with orthopaedic plates ${ }^{10}$. If the authorities were to legislate this, implants would become extremely important for identification ${ }^{8}$. Some companies have already placed lot numbers on implants, which can be visualized even after incineration at $1125^{\circ} \mathrm{C}^{7}$. A disadvantage to placing serial numbers on implants would be the increase in cost because manufacturers would have to adapt their processes to enable this to be done.

One study showed that human identification was possible by means of radiographs of people who were treated with the same implant system ${ }^{5}$. This was because even if the same type of implant were inserted in two different people, the location and bone condition, peri-implant condition, prosthesis, and profile of positioning would never be identical. One study showed that even when the implant was associated with a small bone segment, identification was possible ${ }^{6}$. Therefore, a serial number would be more useful in those cases in which the implant is found completely detached from the bone, which may occur in bodies that have been extremely carbonized.

In the cases analysed, there was no numbering on the implant surfaces; therefore, the morphological characteristics (qualitative) and linear measurements (quantitative) were analysed. The points of coincidence observed in both the implants and teeth showed compatibility of findings that led the experts to determining the positive identification of the bodies. The same technique was used in a similar study $^{11}$ to identify a charred body. Linear measurements between teeth were used in a case report as well ${ }^{12}$.

When an unidentified body with one or more implants is found but there is no record chart available, clues about the type of implant might be able to indicate the direction for investigation ${ }^{3}$. At present, an implant detected in a PM radiograph is susceptible to being mapped simply as an implant, with little information. If the manufacturer's name or the type, width, or length of the implant could be determined with precision and recorded $^{1,2}$, it would increase the chances of discovering the 
implant's origin. Data saved by dental implant manufacturers can be very supportive and represent additional reference data for dental identification ${ }^{13}$. This is very important in the present globalized world, in which there is a great flow of people among countries and there are risks of terrorist attacks, mass disasters, problems with refugees, etc. Identification of the implant could direct the investigations for identification of the victim.

For this reason, a software program known as Implant Recognition Software (IRS) was developed that could identify the system, width, and length of the implant used $^{14}$. This program was created to identify implants and can be used in forensic scenarios. However, currently, the software's database includes scarce data because there are hundreds of types of implants in the world today. Discovering where the manufacturer of the implant found in the body is located could narrow down the possibilities from a list of missing people ${ }^{4}$. However, some companies have imitated the implants of other successful manufacturers ${ }^{4}$. These "clones" may lead to a mistaken identification of the manufacturer; therefore, further studies are necessary to correct this failure.

In some cases, extreme heat will destroy the teeth and restorative materials, as well as other means of scientific identification. Due to their physical properties, implants will resist the heat and maintain characteristics such as the shape and screw thread pattern necessary for identifying the type of implant ${ }^{9,15}$ since they have a high melting point $\left(>1600{ }^{\circ} \mathrm{C}\right)^{16}$. In cases of carbonization, implants may become loose from the bone and be the only evidence available for identification of the body. This justifies the presence of a forensic dentist at the scene of the crime to look for possible implants, particularly around and below the place where the head was $^{9}$. Thus, with the high melting point, titanium is also highly resistant to corrosion, which may be useful in acid or saline environments ${ }^{9}$. As may be observed in Fig. 1 , the heat destroyed the vestibular bone plate and part of tooth 47 , but the implant remained intact.

The options for visualizing the details of implants in unidentified bodies include intraoral exam, intraoral and panoramic radiography, tomography, and direct removal of the implant ${ }^{2}$. Intraoral radiography has the advantages of being cheaper, being commonly used by forensic dentists, and being easier to perform due to the horizontal position of the body ${ }^{2}$. These radiographs were used in the cases reported here because, as may be observed, the AM radiographs were of the periapical type. However, care must be taken when radiographs are used in dental treatment for direct comparison with PM radiographs because the factors of distortion and angulation need to be considered ${ }^{2}$. This is one of the disadvantages of this technique. If necessary, the angulation of the PM radiograph must be changed to diminish distortion.

One study showed that poor angulation and lack of clarity and definition of some images made it difficult to evaluate the threads, heads, and grooves of some implants $^{2}$. This emphasizes the importance of good radiographic images to achieve 
accuracy in identification, as the author showed the difficulty of identifying the type of implant in non-standardized radiographs ${ }^{2}$. Whenever possible, radiographs must be taken with the X-ray beam at the correct angle to the long axis of the implant and the film to minimize distortions, in addition to visualization of the entire implant ${ }^{2}$.

In a real case of identification, it is important to take various radiographs to achieve a clear geometrical image so that all the details of the implant are revealed ${ }^{3}$. In the cases presented, because there was AM material, the PM radiographic image had to be very close to the AM image to enable a comparison to be made (Tables 1 and 2).

The PM detection of an implant would be a sign that there would possibly be AM radiographs taken by a dentist for preand post-operative evaluation and for implant maintenance ${ }^{2}$ because evaluation by imaging exams is essential in implant dentistry ${ }^{1}$. Moreover, complete clinical documentation including radiographs maintained by the dentist could be used as AM material ${ }^{6}$, as in the cases presented.

\section{FINAL CONSIDERATIONS}

The implants found in the bodies were decisive in the process of identification. This identification was only possible because the implant dentists presented complete documentation with good technical quality, enabling an efficient expert approach to comparison of the data. Keeping good clinical record charts is essential; the different stages of treatment must be duly documented, and these data must be preserved with security. It is important to make implant dentists aware of this significant role because they may be asked by the authorities or family members of the deceased to present a complete record chart.

\section{RESUMO}

O objetivo desse trabalho é apresentar dois casos em que os implantes foram essenciais no processo identificação e mostrar a importância do papel do implantodontista nesse processo. Dois corpos esqueletizados com implantes dentais foram encaminhados para exames. Foram analisadas as características morfológicas (qualitativas) e medidas lineares (quantitativas) dos implantes nas radiografias antemortem e postmortem. Os pontos de coincidência observados tanto nos implantes quanto nos dentes mostram a compatibilidade dos achados, o que levou os peritos a determinarem a identificação positiva. Os implantes encontrados nos corpos foram decisivos no processo de identificação. Essa identificação só foi possível porque os implantodontistas apresentaram uma documentação completa e com boa qualidade técnica, permitindo uma abordagem pericial segura no confronto dos dados. Portanto, é importante que os implantodontistas estejam cientes do seu papel já que podem ser solicitados pelas autoridades ou membros da família para apresentarem o prontuário da pessoa falecida.

\section{PALAVRAS-CHAVE}

Ciências forenses; Odontologia Legal, Implantes dentais, Identificação humana; Radiografia odontológica.

\section{REFERENCES}

1. Byraki A, Costea AV, Curcă GC, Hostiuc S. Morphological analysis of dental implantsforensic significance. Rom J Leg Med. 2010;18:207-12.

2. Berketa JW, Hirsch RS, Higgins D, James H. Radiographic recognition of dental implants as an aid to identifying the deceased. J Forensic Sci. 2010;55(1):6670 .
3. Nuzzolese E, Lusito S, Solarino B, Di Vella G. Radiographic dental implants recognition for geographic evaluation in human identification. $\mathrm{J}$ Forensic Odontostomatol. 2008;26(1):8-11.

4. Berketa JW, James $H$, Langlois NE, Richards LC. A study of osseointegrated dental implants following cremation. Aust Dent J. 2014;59(2):149-55. 
5. Ahlqvist J. The use of intraoral radiographs for identification of edentulous patients rehabilitated with implants. J Forensic Odontostomatol. 2016;1(34):1-9.

6. De Angelis D, Cattaneo C. Implant bone integration importance in forensic identification. $\mathrm{J}$ Forensic Sci. 2015;60(2):505-8.

7. Baldim $M$, de Almeida SM, Delwing $F$, Tinoco RLR. Identificação de vítima de afogamento por meio de documentação ortodôntica: relato de caso. Rev Bras Odontol Leg RBOL. 2019;6(2):61-68. http://dx.doi.org/10.21117/rbol.v6i2.242.

8. Berketa J, James H, Marino V. Survival of batch numbers within dental implants following incineration as an aid to identification. J Forensic Odontostomatol. 2010;28(1):1-4.

9. Berketa J, James H, Marino V. A pilot study in the recovery and recognition of nonosseointegrated dental implants following cremation. J Forensic Odontostomatol. $2011 ; 29(2): 38-44$.

10. Matoso RI, Benedicto EeN, de Lima SH, Prado FB, Daruge E, Daruge Júnior E. Positive identification of a burned body using an implanted orthopedic plate. Forensic Sci Int. 2013;229(1-3):168.e1-5.

11. Francesquini Júnior $L$, Ulbricht $V$, Martins AL, Silva RF, Pereira Neto JS, Daruge Júnior E. Charred: Forensic dental identification and scanning electron microscope. J Forensic Dent Sci. 2018;10(3):164-8. https://doi.org/10.4103/jfo.jfds 6518.

12. Belotti L, Rabbi R, da Rocha Pereira SD, Barbosa RS, Carvalho KS, dos Santos Pacheco KT. É possível identificar positivamente um corpo carbonizado somente por dois dentes? Relato de um caso pericial. Rev Bras Odontol Leg RBOL. 2015;2(2):105-115.

http://dx.doi.org/10.21117/rbol.v2i2.29.

13. Mansour H, Sperhake JP, Bekaert B, Krebs $O$, Friedrich $P$, Fuhrmann $A$, et al. New aspects of dental implants and DNA technology in human identification. Forensic Sci Int. 2019;302:109926. https://doi.org/10.1016/j.forsciint.2019.1099 $\underline{26}$.

14. Michelinakis G, Sharrock A, Barclay CW. Identification of dental implants through the use of Implant Recognition Software (IRS). Int Dent J. 2006;56(4):203-8.

15. Berketa J, James H, Marino V. Dental implant changes following incineration. Forensic Sci Int. 2011;207(1-3):50-4.

16. Van Noort R. Titanium: the implant material of today. Journal of Materials Science. 1987;22(11):3801-11. 